\title{
БИОЛОГИЧЕСКАЯ ДЕГРАДАЦИЯ НОМО SAPIENS: ПУТИ ПРОТИВОДЕЙСТВИЯ
}

\author{
Г. Л. Апанасенко \\ Национальная медицинская академия последипломного образования имени П. Л. Шупика
}

\section{BIOLOGICAL DEGRADATION OF HOMO SAPIENS: WAYS TO COUNTERACTION}

Shupyk National Medical Academy of Postgraduate Education

Введение. Перед человечеством стоит проблема, значимость которой пока не осознаётся в достаточной мере ни общественностью, ни наукой - биологическая деградация вида Homo sapiens. Она проявляется ускоренным темпом старения, популяционным снижением «количества» здоровья (жизнеспособности), эпидемией хронических неинфекционных заболеваний (ХНИЗ), полиморбидностью, снижением уровня развития физических качеств и психофизиологических функций, peпродуктивной функции, рождением ослабленного потомства, снижением IQ и многим другим. Всё это является следствием потери устойчивости неравновесной термодинамической системы (живого), т.е. дефицита внутриклеточной энергии, из-за противоречий между биологическими и социальными аспектами эволюции Человека.

Результаты и их обсуждение. В целях мониторинга состояния человека, в основе которого лежит недостаточность потенциала аэробного энергообразования (т.е. функции митохондрий), разработана экспресс-система оценки уровня здоровья, отражающая аэробную мощность, а также устойчивость индивида к самым различным негативным воздействиям - кровопотере, гипоксии, хронической интоксикации и т.п. Ещё 25 лет назад нами описан феномен «безопасного уровня» здоровья (БУЗ), выше которого не регистрируются ни эндогенные факторы риска развития ХНИЗ, ни сами заболевания. Доля украинской популяции, находящейся в зоне БУЗ, за 25 лет сократилась с 8 до 1 \%. В 2011 году феномен БУЗ подтверждён норвежскими исследователями. Обследовав более 4600 практически здоровых мужчин и женщин, они отметили, что у женщин с показателем удельной аэробной способности (МПК/кг/мин) ниже 35 мл в 5 раз, а у мужчин ниже 44 мл/кг/мин в 8 раз чаще встречаются факторы риска развития сердечно-сосудистых заболеваний (наши критерии «безопасного уровня» здоровья - 35 и 42 мл/кг/мин соответственно. При этом каждое снижение удельного МПК на 5 мл сопровождается увеличением выраженности и распространённости факторов риска сердечно-сосудистой заболеваемости на $56 \%$.

Выводы. Противодействие биологической деградации человечества заключается в переводе основной части популяции на более высокий уровень потенциала аэробного энергообеспечения функций. С этой целью предлагается в дополнение к существующей «индустрии болезней» (учреждения Министерства здравоохранения) формирование «индустрии здоровья», массовый спорт, совершенствование системы физического воспитания и пр. Цель - достижение БУЗ большинством популяции. Цель недостижима при отсутствии системы мониторинга уровня здоровья. 